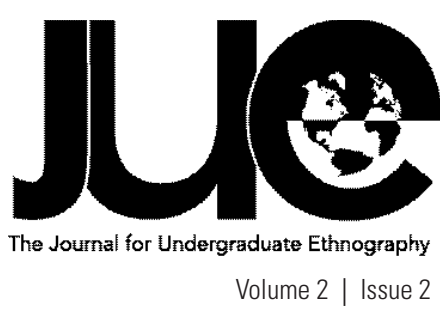

\title{
Imagining a Classroom: Negotiating Diverse Interests of Educational NGOs in Northern Ghana
}

\section{Grace Leonard}

University of Richmond, grace.leonard@richmond.edu

\section{ABSTRACT}

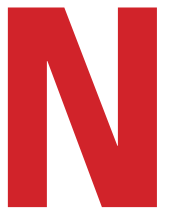

on-Governmental Organizations ('NGOs') compliment imperfect educational models with creative and flexible community-based programs. In Northern Ghana, children in poverty often face diminished educational outcomes, and organizations use various strategies to seek justice for these children. NGOs negotiate an uneasy existence as mediators between the spheres of structural bureaucracy and local poverty. NGOs must maintain a delicate balance between serving the cultural and structural challenges facing education in resource-poor communities. Solely focusing on either aspect robs the organization of local legitimacy NGOs appropriately apply complex social context to their simplified program goals when staff relationships with local communities inform what tools oppressed Ghanians need to live flourishing lives. Structural interviews in Tamale, Ghana, illustrate that NGOs achieve their goal of improved educational outcomes for poor children when they identify as members of the community where they work.

Keywords: Development, Education, NGO management, Community Rapport 
FIELD NOTES, NOVEMBER 16, 2010

Visiting a classroom outside Tamale, Ghana, it is difficult to tell that none of the children sitting in desks have been enrolled in formal school. A young adult from the community is leading around twenty students through a reading exercise. He was trained to teach by the NGO

Literacy Support, which operates afternoon programs for children who help with farm chores during formal school hours. These students are speaking their native tongue, Dagbani, rather than speaking English, the language taught to middle-grade students in the formal system. The

children follow along in their books (the NGO has provided a book for each child), and children raise their hands to answer when the teacher asks a question or calls on them by name. A few students are called to the front to demonstrate on the board. The class is divided into a large group activity, a small group activity, and independent reading. I sit in the back of the classroom with a program field manager who provides context and asks me to sign a guest book.

\section{INTRODUCTION}

Education is commonly a part of the agenda to reduce poverty (Apple 1982: xvii). I seek to closely examine how NonGovernmental Organizations (I will use the abbreviation NGO) seek to support subsistence farmers in Ghana towards succeeding in formal school systems. I find NGOs are appropriately incorporated into local communities when staff members place their community identity before their organizational identity. By incorporating civic obligation into their business model, NGO staff members are able to provide an educational environment that fosters the empowerment of children in Tamale through a worldview that is relevant and real to them. This paper seeks to illustrate how NGO education programs establish rapport with families and translate quantified strategic goals to complicated social context.

In the fall of 2010, I participated in the School for International Training's study abroad program in Ghana called, "Social Transformation and Cultural Expression." I worked with NGOs involved in education in the Northern city of Tamale for a fourweek independent study period. Tamale is the hub of NGO activity-grassroots, multilateral and bilateral-in Ghana, making it an excellent case study. I explored how NGO staff imagine positive change in the disadvantaged communities where they work and why they value education as a step towards development. NGOs are prolific in Tamale, Ghana, and all must mediate between rural Ghanaian communities' needs and desires as well as international institutional communities' missions and goals. (Field notes 11/10/2011).

During a month of fieldwork in Tamale I focused on eight organizations aiming to expand the access and quality of education in the North. Some of these groups chose to make education their only focus, while for other groups, education was part of a larger vision, and in addition to education programs, others were also implemented, in areas like agriculture, public health, climate change, and women's rights. Each NGO was approaching the challenge of development through education in a slightly different way. Organizational offices in Tamale distanced from rural villages where programs were being implemented. However, they were closer to grassroots social issues than their international donors. As an intermediary between the two, offices in Tamale translate the realities of education in underdeveloped communities into the economic and social scientific context of a developed community. 
Rather than marking NGO programs as successes or failures, I hope to articulate how they work and why they work the way they do (Mosse 2002: 646; Crewe and Harrison 2002: 7). I admit my inability to prescribe perfectly from a distance, and proclaim the ability of Ghanians students to tell their own story. My development perspective "places developers and the developed, self and other, within a common framework" (Van Ufford et al. 2005: 5). It is key to examine the influence of community members compared to funders in NGO management (Kisanne and Gingerich 2004: 312). NGOs carry out collaborative and appropriate education agendas in poor communities when the staff sees themselves as part of the local community. As perpetual middle-men, NGO staff constantly work to translate the needs of the community to funders and board members (Crewe and Harrison 2000: 89). In this process, the organizations' rhetoric, assumptions, goals, and views of success all influence the staff's perspective of the community. In addition to theory, NGO websites, brochures, and interactions with community members will be interpreted.

Several terms specific to development and NGO institutions will be used throughout this article. "NGO" will be defined as independently funded institutions that aim to improve public access to social services. All NGO's will specifically focus on the issue of public education. "Development" is the same economically motivated process of national improvement commonly used in literature (Lewis 2005; Ferguson 1994: 55) I contest the assumptions implicit in this definition. The term "funder" will refer to the individuals, institutions, companies, or governments that provide monetary support to NGOs. The names of organizations I partnered with and the names of my informants have been changed or shortened to initials throughout the paper for their privacy.

The populations served by these educational NGOs would commonly be designated as "poor" by development organizations, academics, and the citizens' own governments (Escobar 1992). I find the term poverty in the English language simplifies the many ways an individual can be described and highlights their deficiency of economic and material resources. An economic definition discounts intrinsic cultural values associated with communities that lack wealth in the economic sense. Students and families who participate in educational NGO programs will often be termed "the oppressed" throughout the paper.
Naming economically poor populations as oppressed speaks to the power exerted in the process of creating poverty (Freire 1970: 48). The NGOs studied in this project are working against many types of oppressors: biased policies, racism, capitalistic goals, and stereotypes. Poverty does not exist passively: it is the byproduct of the active decisions of oppressors. Legitimized national school agendas have the power to encourage social conformity through discourse. NGOs must work to understand and relate to the conflicting norms of the oppressed and the oppressors.

My research is based on formal interviews with NGO staff at several organizations in Tamale. The offices I visited in Tamale were often management hubs for anti-poverty programs implemented in rural areas outside the city. Aside from a visit to a Literacy Support program site (a forty-five minute motorcycle ride outside the city), I remained in Tamale. My findings in Tamale were focused on the rhetoric of staff. Though informative, usually their interviews couldn't easily be juxtaposed with their actions. I did not get extensive time in the field to observe the relationship between how my informants discussed education and how they enacted education daily. I was distanced from individuals experiencing the poverty each NGO was combating.

My fieldwork illustrates the constant negotiation between power relationships and human agency in community-based education. In Ghana I learned about empowerment. I learned about about raising individuals up and giving them means to shape their own world towards community. What if the NGO's goal of improving literacy rates or government testing scores simultaneously degrades students' reliance on valuable neighborhood kinship networks? Who am I to say whether a formal education can take a child, whether in the city or on a farm, and penetrate her soul and engage her mind? Certainly NGOs must admit their own biases regarding school curriculum, kinship relations, and "right" citizenship. But overemphasizing the influence of institutional management in community change furthers a framework of injustice (Van Ufford et al. 2003: 9). I find NGOs' understandings of social justice are subjective to the locality they are in.

Justice for the oppressed is not directly correlated to a strategic plan, but involves the NGO and the government, the NGO and the family, the NGO and the community, the NGO and the school. "Stability in the world of action does not come from coherent policy, but from effective relationships" (Mosse 2005: 130). 
I am interested in NGOs as institutions because they are incubators for creative ideas about social change. Fair collaboration with the oppressed is a problematic challenge, but it is possible, and it is necessary. The theoretical debate between structure and agency applies to both development and education.

\section{THE MANAGEMENT OF EDUCATION IN GHANA}

\section{SITUATIONAL CONTEXT: NGOS IN TAMALE}

Today, Tamale is a city with a population of 360,579 where the primary language besides English is Dagbani (Mongabay. com 4/5/2012). I sat down with my advisor and primary informant my first week working on this project. The Executive Secratariat of a local NGO, a Muslim, and a Northerner; he provided context for the region based on his organization's research and his own personal experience. Around 15 percent of the country identifies as Muslim; the majority of the Muslim community resides in the Northern region where Tamale is located (Personal Interview 11/10/2011). The city is bright and busy, and residents tend to carry themselves with a quiet assurance that is welcoming. The North of the country faces unique challenges regarding economic development due to its culture and particular history, thus today there is a higher concentration of NGOs in Tamale than anywhere else in Ghana.

The first informal school in Ghana opened in Cape Coast in the 1600's (Personal Interview 11/10/2010). Schools blossomed in the south in the ensuing years, concentrating around the more populated areas of Cape Coast and Accra. Missionaries worked to establish many schools during the height of colonialism. The first public school was not established in the North until 1906 (Personal Interview 11/10/2010). Before 1906, literacy in the North would have primarily served the purpose of reading the Qur'an; historically the Northern regions are dominantly Muslim while the South of Ghana was predominantly Christian (Personal Interview 11/10/2010). Wealthier Muslims in the North may have had the opportunity to further their religious education, but their education was not necessary for economic reasons until after colonialism (Roberts 1982: 168).

Rather than establishing the individual's role in a local community, public school systems establish the individual's role within the nation as a citizen and a worker (Burbules and Torres 2000: 2-3). As education became nationalized it began to embrace conformity within government boundaries.
Today, the Northern, Upper East, and Upper West regions of Ghana are working against history as they strive to operate Ghanaian national schools. In 1961, the Ghanaian government made a commitment to provide free compulsory education for all children (Roberts 1982: 168). Prior to 1906, children in the North participated in systems of upbringing in their communities that prepared them appropriately for their roles as farmers, hunters, or housewives (Personal Interview 11/10/2010). Northerners historically have created systems to prepare individuals for life in subsistence farming communities. It was not until the last century that the population began to be educated under a national scheme that would equip individuals as Ghanaian citizens. Students whose culture or livelihood contradicts with the public school's agenda frequently face diminished educational outcomes (Bourdieu 1973: 496). The nationalizing of schools has led to the 'reproduction of class relations' through its agendas related to both economic progress and cultural knowledge (Apple 1995: 38).

Parents in the North are still motivated to have large families based on subsistence farming lifestyles that requires a group of laborers. In 1993, the Ghana Statistical Service found that three percent of children in Ghana were not enrolled in school because they were needed for farm labor, while in the Northern region, eleven percent of children were kept at home to farm (Botchway 2001: 40). According to the Ministry of Education, from 2005-2006 there were at least 1,989,910 children between the ages of six and twelve that were not attending school in Ghana, with up to twenty percent of them residing in the three northern regions (Casley-Hayford 2007: 25). Entering and successfully completing the formal education system in Ghana necessitates some social and economic capital that is not possessed by most subsistance farmers.

This statistical problem translates to a development problem that has been removed from farms, food stands, remote dwellings, and rural communities and placed in grant applications and development benchmark plans. Development standards for education in Ghana trace back to an Anglo-Saxon tradition of formal schooling, and this heritage communicates a problematic message about the culture of a successful citizen (Apple 1995: 38). The statistics above are often coupled with statistics describing economic resources: In 2006, 9.6 percent of the Northern region's population was living at the poverty level 
and the poverty gap, which is generally regarded as living on or below $\$ 2$ a day. Poverty in Ghana has been reduced from 52 percent to 28 percent in the last ten years. Living at the poverty level is generally defined as living on or below two dollars a day (World Bank 4/5/2012). Is it appropriate to assume education will lead to wealth, and that wealth is the appropriate end goal?

In Tamale, Ghana, one staff member of a multilateral organization scoffed when asked why formal education is important for Ghanaians today: "Why are you asking me?! It is everything. We want to be like America. We want to move to modern society. I should be able to go to the Netherlands, the United States, or Canada and function. [Listening to the] radio, [watching] TV, and community participation require literacy" (Personal Interview 11/16/2010). This informant represented a European organization involved in many different aspects of development, including agriculture, public health and education. Though he was Ghanaian himself, he did not embrace his national identity. $\mathrm{He}$ clearly illustrates, "the idea of development promises that one will be able to feel at home everywhere in the world" (Gronemeyer 2001:60). I left his office with a booklet clearly outlining the quantifiable outcomes of his organization's initiatives in the country. The numbers aligned with his speech-an enormous simplification of social reality on the ground.

According to critics of international development, the informant is saying to Ghanaian youth, "My institution will define 'the good life' for you." The informant assumes a tie between improvement and acquisition of technological knowledge-hinting at social evolution (Crewe and Harrison 1998: 25). Critical development theorists highlight the tendency of NGOs to associate development with modernity and dissociate development with tradition (Crewe and Harrison 1998: 25). The social theorist Foucault argues that when discourses like these regarding a particular lifestyle are made legitimate, individuals conform to the discursive norm rather than questioning the source of its power (Foucault 1979: 11). Rhetoric has been developed surrounding the elimination of poverty, while critics argue the development system has only furthered poverty (Moyo 2009:46).

Importantly, when the NGO's worldview becomes real to oppressed populations, there is the potential for what Freire, author of Pedagogy of the Oppressed calls 'cultural invasion' where the standards and goals of the 'invaders' become the standards and goals of the 'invaded' (Freire 1970: 180). Freire moves be- yond Foucault's restrictive power and sees a way for the individual to free herself from the system. Dialogue is key to effective empowerment, and ensures NGO the staff is wary of the consequences of biased leadership (Freire 1970: 180). Pedagogical dialogue between an educator and a student will dissociate dependency and oppression by liberating students to enact their own futures beyond constraining cycles of poverty (Freire 1970: 90, 103). Development is complicated as is any inter-cultural communication. But, interaction between the elite and the oppressed is imperative in order for social justice to occur for the oppressed. NGO projects have the potential to empower the communities they serve.

Upon entering an NGO office in Tamale, one can expect to be greeted in a reception area by a knowledgeable secretary or sometimes by a security officer who keeps a log of visitors and directs individuals to reception. I never had trouble conveying my project at the front desk, and office staff was always informative and helpful. When waiting in the reception areas of offices for the appropriate staff to become available, I often noted that NGOs used wall space in waiting areas to publicly display their mission, goals, and/or accomplishments. The guests anticipated in each waiting room could be gleaned from the information available. Ghana Organization for Education Development (GOED) had a waiting room which housed two bookshelves full of binders-many with the names of education related NGOs on the spine. An emphasis on data collection was made clear from the moment I walked in the door-identifying GOED's concentration on policy and advocacy rather than field programs. Other organizations, like AVF used wall space to educate--not about the organization itself, but about public health (i.e. HIV protection, women's rights, safe-sex practices). This use of space indicated that the guests welcomed there could be of multiple identities --both community members who were receiving the services of the organization, or donors coming to learn about an NGO's field programs.

The office space of each organization felt particularly counter to the crowded markets and scattered neighborhoods of Ghana. I was welcomed to offices with cold rushes of air conditioning - one of the few places in Tamale I'd felt air conditioning. Open waiting areas were attached to comfortable and private offices. Staff reflected and communicated their identity in the organization through dress in a variety of ways. Many dressed 
in more traditional batik, while others chose suits with ties. Importantly, every staff person I interviewed was Ghanaian, and I only saw one staff person from Europe and none from the United States in my time visiting eight different organizations. The proliferation of development initiatives in Ghana has lead to a varied array of institutions within the city of Tamale, and development institutions are considered reputable employers.

In order to carefully analyze how each group utilized different modes of communication to engage both donor groups and benefiting communities, I have broken five NGOs into three different categories. The first, "International" organizations will be defined as NGOs possessing offices and governing bodies in other countries. Usually their goals and programs all fit under a larger vision of international development. The extent to which international organizations tailored their educational initiatives to local situations varies tremendously. Critics say international organizations are more likely to be motivated by economic improvement (Goldman 2005: 29). These organizations are increasingly interested in understanding local social context. In Tamale, locals often speak highly of the United States. My field notes from November 18, 2010 describe an international NGO.

My mind was swirling as my Merrell sandals padded along a red dirt road in southern Tamale, Ghana. I am determined to make it to my appointment with an NGO without asking for directions... I turn the bend and am greeted by a grand log cabin that sticks out on the hot, flat landscape and contradicts the concrete and metal structures along the road. A flag representing the Western donor's country, and the Ghanaian flag, fly side-by-side in front of the building. The sign proclaims I have found the right place, but first I must pass a security guard in a booth in front of a gated entrance. The guard is friendly and has me sign into a guest book.
GHRW has certainly constructed an image to communicate a certain message, but I am not sure the majority of Ghanaians would resonate with a log cabin.

The three international organizations interviewed were, AVF, UNGIO and GHRW. GHRW is an NGO with its headquarters in Toronto, Canada and field offices in several developing countries. GHRW works in nine out of twenty districts in Ghana. The five focus areas of their programs include education, health and nutrition, water and sanitation, sustainable livelihood, and strengthening institutions. As a linking NGO, GHRW provides support to local NGOs in the form of school supplies, rain harvesting equipment, furniture, school buildings, lunch food, and teacher training (Personal Interview 11/18/2010). GHRW seeks to create a relationship between the Canadian public and children in Northern Ghana through their child sponsorship program.

AVF is headquartered in the Netherlands. AVF also works in West and South Africa, the Balkans, and Latin America. According to their literature, their goals are twofold, for (1) "effective, efficient and increased access to and delivery of basic services and (2) sustainable and equitable production, income and employment for the poor" (AVF). Rather than working with local NGOs to deliver tangible services, AVF provides consulting services to NGOs and uses the three steps of analysis, action, and assessment to guide the process (AVF). While services are being provided, AVF meets with NGOs on a weekly or monthly basis. In terms of education, AVF in Ghana works towards these two goals by supporting the government's implementation of the School Feeding Program, consulting district-level Ghana Education Service directors, and evaluating how the Ghana Education Service collects data from schools (Personal Interview 11/18/2010).

In Ghana UNGIO is specifically interested in supporting gender parity in school enrollment, the training of teachers, and the quality of teaching in the classroom (Personal Interview $11 / 16 / 2010)$. Rather than working through partners or implementing their own programs, UNGIO focuses on developing policy and following how it is implemented in the formal classroom. The organization signs a contract directly with the government to work in Ghana and spends more time working with district supervisors than individual schools. Though 
sometimes they provide grants to NGOs, UNGIO's first priority is to determine the areas where the government needs support implementing policy (Personal Interview 11/16/2010). UNGIO is unique from all other organizations studied because the organization's larger vision is inspired by the United Nations, a politically motivated body. Still, UNGIO incorporates fieldwork as an important part of their planning.

Secondly, Literacy Support will be defined as a "Grassroots" organization. Literacy Support is now independent, but began as a partner program through a grassroots NGO involved in education, job training, and local agriculture. There is an important distinction between Literacy Support and the international NGOs. Literacy Support articulates their origin as the result of a "friendship" between Tamale and their Danish partner, rather than being borne of international goals, development norms, and global politics. Personal relationship has motivated the organization since its origin, and this has led to differences in management. Literacy Support work is by and of the community in a way the international NGOs never will be. Locals were instrumental in forming the programs, and remain a foundational part of the organization's management and strategic planning (Personal Interview 11/10/2010).

Literacy Support provides small literacy classes to out of school children ages eight to fourteen in all five districts in the northern region, with around forty classes in each district (Personal Interview 11/15/2010). The communities where the programs operate change every three to five years, and these communities are targeted based on their population of out of school children. An important aspect of the Literacy Support approach to literacy is teaching children in their mother tongue, so that they can apply their skills daily and gain confidence in their abilities. Literacy Support classes are taught by a local community member who is literate in the local language, and familiar with students' backgrounds. Historically, teachers in Ghanaian schools were not from the area where they taught and did not speak the same language as the community (Roberts 1982: 269). Literacy Support aims to equip children who are not in school in the north to successfully transition to the formal system.

Finally, the Ghana Organization for Education Development will be referred to as an "advocacy" organization:

\section{THE WAITING AREA IN THE GOED HEADOUARTERS CONTAINED BOOKSHELVES PACKED WITH BINDERS DESCRIBING DEMOGRAPHICS AND REPORTS ON LOCAL SCHOOLS. THIS PUBLIC DISPLAY OF SOCIAL ANALYSIS WAS SUPPORTED BY MY CONVERSATION WITH A GOED STAFF PERSON, WHO ARTICULATED THE CHALLENGES FACING EDUCATION IN NORTHERN GHANA WITH BOTH CONCRETE FACTS AND SENSITIVITY TO LIVELIHOODS IN LOCAL VILLAGES. WHEN ASKED WHY FORMAL EDUCATION IS IMPORTANT FOR YOUTH IN NORTHERN GHANA, HE REPLIED: “ONCE [COMMUNITIES BEGIN TO BE MORE] EDUCATED, ISSUES OF POVERTY, DISEASE, [PUBLIC] HEALTH, AND AGRICULTURE, WILL ALL IMPROVE. INDIVIDUALS CAN LEARN HOW TO BUDGET PROPERLY AS A FARMER, LEARN TO THINK CRITICALLY AND ANALYZE ISSUES" (PERSONAL INTERVIEW 11/25/2010).}

Though GOED is not directly involved in planning or initiating a development program, it has collected important qualitative and quantitative data regarding the state of education in the North of Ghana. The organization's articulations of local challenges facing education provide insight into the translation process of development partnerships (Crewe and Harrsion 1999). Rather than implementing programs, GOED is more interested in tracking the effects of existing programs and analyzing the current state of the school system. Their vantage point as an NGO critiquing the state of the education system is extremely valuable. Today international, grassroots, and advocacy organizations are all informing the educational training of youth in northern Ghana. 


\section{NGOS'PERSPECTIVE ON EDUCATION}

Over the course of one month of discussions with NGO program directors, it became obvious that it is important to keep NGO's and their donors aligned under a common goal. Staff are also aware that a shortcoming of the goal is its generalization of program implementation globally: "we need a standard globally, but what is most important is how implementation is translated locally... Not all countries have the same resources so each country's plan for implementation must be different" (Personal Interview 11/10/2010). All NGO staff members were in support of the goal to enroll all students in formal school. This common goal eases communication between NGOs, their partners, their donors, and the government because they are all receiving direction from the same external source, and also heightens healthy competition between organizations.

All of these NGOs in Ghana have institutionalized and normalized international development. Ghana has been the beneficiary of loans and structural readjustment programs through international development agencies like World Bank, UNGIO, USAID and the International Monetary Fund. Improving the productivity of "Third World" economies first became a political priority for the United States during the reconstruction of Europe following World War II (Lewis 2005). By 1965 , "Ghana... had received as much as US $\$ 90$ million in aid flows" (Moyo 2009: 15). Economic structural adjustment prioritized global trade and economic productivity over developing sustainable economic practices. Thus, for multilateral development organizations in the business of international aid, "successful lending is measured almost entirely by the size of the donors' lending portfolio, and not by how much of the aid is actually used for its intended purpose" (Moyo 2009: 54). Critics advocate economic strategies that emphasize self-sufficiency, rather than furthering dependence (Moyo 2009: 145). Today, these NGOs in Tamale rely on funding from these large governmental and multilateral organizations, and they therefore must often translate and juxtapose their local agenda through global agendas (Goldman 2005: 29).

The Millennium Development Goals are a globally influential set of development standards that NGOs in developing countries often use to shape their own goals. The MDGs were developed by the United Nations, and the goals outline a set of milestones to be met by all developing countries by the year
2015 that work to eradicate poverty. Literacy Support, AVF, and UNGIO all cited the education specific MDG goal-- that all children will be enrolled in primary formal education by 2015when articulating their management strategies (Personal Interviews 11/2010). International development strategies prioritize raising foreign capital, and can thus systematically undercut the capacity of governments to construct educational policies that enhance educational equality or seek to develop some degree of national anonymity in the context of research and prevent governments from adequately addressing how to make culturally specific education for their citizens accessible to all (Burbules and Torres 2000: 43). Education becomes an economic investment. NGOs like Literacy Support and AVF are dependent on grants from large, powerful agencies like the World Bank, the IMF, and the United Nations. These organizations are focused on global improvements in economic productivity. When distributing funds, they run the danger of prioritizing quantifiable productivity over context-specific and sustainable outcomes (Escobar 2001: 140).

A structure of quantifiable outcomes has become the norm since the meeting of Breton Woods in 1944 when the World Bank was organized to help rebuild Europe after World War II (Goldman 2005: 30). This pivotal political partnership led to a new American agenda of providing international economic development assistance. Supporting 'underdeveloped' countries has thus come to mean assuming the improvement of livelihoods is tied to increasing economic productivity. Many NGOs, in order to maintain funding and an amiable public image, often produce their own reports and statistical data to show the impact of their programs over time. But, this power does not dictate the actions of program participants (Crewe and Harrison 1998: 77). Organizations should be aware of realistically portraying the challenges of Northern Ghana to donors, but donors' policy prescriptions will not restrict the agency of students.

Currently, families in the three northern regions still largely rely on farming as their primary source of subsistence and income. This agricultural tradition combined with the Islamic tradition in the north makes for unique cultural norms that sometimes conflict with the expectations of the nationalii school system. Thus the Ghanaian government has found it challenging to incorporate oppressed farming families into schools. 
There is a tradition in some northern communities of an adult brother giving his daughter to his sister's family to be raised and trained as a housewife, a practice called fostering. Such a practice establishes good will between family members, but it in the process neglects the young women fostered and their educational opportunities (Personal Interview 11/15/2010). Historically, the girls who do enroll in school in the northern regions drop out at younger ages to be married. With this cultural practice in mind, one can imagine that northern communities may see the formal education system as distancing children from a way of life seen as valuable (Casely-Hayford 2007: 99). In fact,

\section{families in Northern Ghana are still relatively new at using the [national education] system as a means to human and community development. Communities are therefore still in a process of learning as to what level their own wards can attain and what type of benefit this would have in comparison to the traditional approaches of child upbringing and indigenous education (Casely -Hayford 2007: 99).}

NGO staff in Ghana have established education that will improve quality of life for children of the Northern regions, and are work to communicate their reasoning to families.

When NGO directors were asked why formal education is important for the people of Ghana, all mentioned improving the ability of the individual to move Ghana ahead amidst increasing globalization today. Local NGOs, through their international partners and relationships with the formal system, have come to value individual achievement reinforced by the formal system. Ghanaian communities in Africa traditionally uphold "communal values," which poses a potential conflict with NGOs' goals of individual student achievement (Casely-Hayford 2007: 79). NGOs often say they must "sensitize" these rural farming families on the benefits of a formal education. This is not a new hurdle: before NGOs advocated education in northern Ghana, the government and missionaries advocated the same in the south of Ghana and experienced similar resistance to education, which rural farming families viewed as individualism as counter to their own cultural practices (Roberts 1982: 269). Rural areas in the north are still learning how to justify this individualism.
Communicating the benefits of an education is an important challenge facing the education sector in northern Ghana. NGOs have the potential to simultaneously raise the voices and provide the tools for communities to construct their own healthy and sustainable lifestyles (Melkote and Steeves 2001). Educational NGOs provide an important transition guiding subsistence communities into the formal system because they facilitate communication.

The government utilizes the support of NGOs in order to achieve these goals (Clark 1992: 152). Once the issue of school attendance is addressed, the formal system must be able to grow as the school population grows. The system is currently stretched beyond its limits as NGOs and Governmental organizations are successfully enrolling more children in school. Classrooms are becoming overcrowded. One NGO informant recalls seeing sixty students in one classroom (Personal Interview 11/10/2010). There are teacher shortages in the north. Seventy-six percent teachers commute from cities, and so arrive to class late and leave school early. In Ghana teachers are sometimes placed on probation for high absenteeism. If this happens, a teacher is expected to teach without pay, but this only increases the teacher's motivation to miss class (Personal Interview 11/25/2010). NGOs articulate many reasons why teachers are to blame for problems with the school system, but historically, teachers have not felt valued or supported by their communities or district governments (Roberts 1982: 277). Today, lacking supervision of teachers remains a problem (Personal Interview 11/16/2010). One organization in particular, Ghana Organization for Education Development, has done extensive research on the public system. NGOs are not only working to increase access to education, but also on the more complex challenge of increasing the quality of an education.

Overall, these NGOs have all made the decision to advocate for broader political change. They make the important decision to move beyond "permanent service-delivery" and towards active participation in government reform (Clark 1992: 161). They must mediate between the spheres of policy and education. NGO education programs independent of national governments are still influenced by national agendas, whether through funding, testing standards, or multilateral development strategies (Melkote and Steeves 2001: 152-157). NGOs have the potential to create agendas that are more sensitive to local situations. 


\section{DISCUSSION: COMPARING ORGANIZATIONAL GOALS AND IMPLEMENTATION}

In Ghana, there is a distinct line between NGO management and program implementation. I was only able to delve deeply into the management side of community development. In a transient sphere between the worlds of neoliberal policy and cyclical oppression managers most often quantify complex social situations. Harsh et al describes how organizational spheres communicate using "structures of accountability" (Harsh et al. 2010: 257), and asserts that neither the instrumental nor the critical perspectives of development accurately portray the relationships between organizational spheres. Though this rhetoric is potentially oppressive itself, having several distinct hierarchical levels within NGOs in Tamale facilitates communication (Ospina et al. 2002). Offices in Tamale foster NGO incorporation into communities because organizations know their business minded atmosphere would prohibit educational programs if offices were in rural villages. By moving between Tamale and villages, students are more able to see their education as something they own.

The physical location of NGO offices provides what Harsh et al (2006: 259) refers to as a 'locational advantage, midway between donors and recipients." This situation parallels the role NGOs play in facilitating communication between donors and recipients (Melkote and Steeves: 2001), and investing in an advantageous location will allow the organization to more easily create financial capital in local communities (Harsh et al. 2010: 260). Because offices and field programs require distinct spaces, mobility is important for organizations. Also, organizations define themselves as boundary crossers through their vehicles labeled with NGO programs that can be seen traveling through Tamale daily. They also must be ready to physically operate different aspects of programs in both urban and rural settings.

Though educational NGO's exist to instill social skills valued by civil society in Tamale, their programs operate more like businesses than schools. Staff should ideally be able to solely cultivate their identity as teachers that belong to a particular community. More often, however, staff must be fluent in the language of the social sector and the private sector, of education and business management. As has been illustrated thus far, these processes of translation provide insight and guidance, but do not determine program effects (Mosse 2005: 647). In Tamale, program managers have satellite offices separate from the classrooms where NGOs operate, and this physical distance has the potential to magnify the disconnect between pupils and donors.

In 2007, Casley-Hayford completed an impact study for the NGO Literacy Support. The study compiled the ways Literacy Support has impacted students, parents, communities and facilitators since its inception in 1995. Findings were collected based on seventy-seven interviews of participants and their families. Importantly, Casley-Hayford found Literacy Support is culturally appropriate to its northern students. The program provides literacy classes for out-of-school children in all three northern regions, meets in the afternoons, allowing children to attend after completing the chores and farm work that keep them from attending school. The program also reinforced community values like respect for elders (Casley-Hayford 2007: 49). The government attributes at least 2-3\% of increase in school enrollment to the Literacy Support program, which encourages participants to enter formal school after a year of literacy classes (Casley-Hayford 2007: 17). It is important to note the differences that Literacy Support participants cited between the Literacy Support program and their later experiences in the formal system, which included: "methods and commitment of teachers, free books, ability to take books home to read, absence of school uniforms, flexible timing of classes, and the medium of instruction" (Casley-Hayford 2007: 18). Literacy Support is currently exploring how best to streamline their program so that it can be expanded to other NGOs and as a complementary system employed by the government. The very publication of the impact study is evidence of the NGO office as a translator of an underdeveloped community into the economic and social scientific context of a developed community.

Organizations like Literacy Support and GOED understand the imperative to use contextual adaptability to inform political conversation regarding national school reform in Ghana. Because organizations have the flexibility to respond to local situations, they are well situated to provide recommendations for policy change. In recent years, as NGOs have begun to lobby and the government's attention has been brought to the state of education in the North, new programs have been launched to help poor families send their children to school. Until the programs gain substantive funding and leadership, they will remain challenges in and of themselves. Two of the main programs are 
the Capitalization Grant and the School Feeding Program. The existence of such programs--the former to cut school fees and the latter to provide school lunches--represents the progress of the relationship between NGOs and the Ghanaian Educational Service. Though several officials I spoke with were involved in these partnerships, staff admitted on more than one occasion these program still have many flaws to be worked out. NGOs have the potential to facilitate to ensure changes do not increase state power too much (Ferguson 1994: 256).

The Capitalization Grant scheme was intended to abolish school fees for students by giving each school an allotted amount of money calculated by the number of students attending the school. This lump sum is intended to help contend with maintenance costs for the classroom and purchase of classroom supplies. NGO research has found that the distribution of these funds has been mismanaged, as money has to move from the national to local level. As well, discrepancies in attendance records between the local, district and national level mean that funds may not always be distributed adequately. The School Feeding Program started in 2005 with the hopes of improving "enrollment, attendance, retention, and gender parity in basic education" (AFV booklet). The program supports local farmers by using local food to produce a meal for students. Unforeseen challenges that grew out of the project include inadequate physical infrastructure and an insufficient number of teachers to handle the increase in enrollment. There was also a "huge government influence" in the School Feeding Program whereby the political party in power was distributing more food to its constituents, rather than the population as a whole (Personal Interview 11/18/2010). These two programs have proven to NGOs that the issues of teacher shortages, classroom infrastructure, and quality curriculum must simultaneously be addressed with the issue of enrollment.

Literacy Support is able to digest these policy issues and bring them to local communities where high numbers of children are out of school. In order for Literacy Support to establish a school, it was agreed that the community must: sign a contract, identify out of school children, and hire someone from the local community who is unemployed but trainable as a teacher. Once the Literacy Support classroom opens, a community council is required to support the needs of the teacher and ease parents' hesitations regarding education. "The other kinds of power- power to, power with, and power from within-may be instrumental in attaining greater power over" (Melkote and Steeves 2001: 36). When NGO staff mingle and build relationships with disadvantaged communities, people from isolated poverty realize another reality is possible. Cultural norms of the poor and the oppressed must be revalued for organizations to truly complete the empowerment they profess.

The director of Literacy Support, whose office is in Tamale, believes it was important to engage student's perspectives rather than changing them, and to work through the local, rather than the national language: " the teaching methods in formal schools needs to be changed to incorporate activity and discussion to keep students engaged. By teaching in the mother tongue, they are also more confident" (Personal Interview 11/15/2010). NGO staff negotiates policies and management strategies in the classroom (Mosse 2005: 2; Crewe and Harrison 2002: 135). Rather than imposing the British model of schooling and assuming it will improve rural students' lives, Literacy Support embraces the cultural reality of communities and incorporates it into their futures. 
FROM THE LITERACY SUPPORT WEBSITE:

"The Ghana Living Standards Survey (2000) reveals that poverty rates are increasing in deprived areas of the country particularly where there is extreme poverty. The Northern, Upper East, Upper West, Central and Western Regions have the highest incidence of poverty where more than $50 \%$ of people live below the poverty line (i.e. live on less than 1 US Dollar per day) and as many as 30\% live below the extreme poverty line (i.e. people living on less than $1 / 4$ of a dollar per day). Nineteen of the 40 most

deprived Districts in Ghana fall within the 3 northern regions. One clear indicator of this deprivation is the fact that educational development in Northern Ghana lags behind the rest of the country.... In response to the peculiar educational problems in Northern Ghana, the Literacy Support programme was developed... aimed at assisting children attain basic literacy skills and then integrate into the formal educational system."

\section{ACTION QUANTIFIED?}

Literacy Support summarizes their programs on websites, brochures, and in other publications to explain their mission and market their strategy to potential donors and community partners. This rhetoric is not reflective of the daily work NGO teachers put in with students on a daily basis. I have illustrated value must be given to local action that takes place in addition to, or in spite of, organizational policy (Van Ufford, et al. 2003: 9). Critical development scholars may discredit organizations based on their narrow definition of development, as illustrated above (Ferguson 1996: 256). Implementation of projects reveals a fuller, more contextual perspective of Tamale than need be shown in these advertising pamphlets. In this final section, I hope to reevaluate the assumed goal of perfecting management, with a moral imperative to give academic value to hope in action (Van Ufford et al. 2003: 6).

Teachers at Literacy Support identify with their organization's official articulations of their communities and their work. NGOs use websites, brochures, and data reports to convey situational qualitative social context with simplified quantitative context. This process of simplification is used to communicate management strategies and marketing strategies. Highlighting NGOs' institutional discourse surrounding the communities where they work will be a primary focus of this section. Illustrating communities through numbers, management strategies, and demographic benchmarks has important limitations that should not be overlooked (Goldman 2005:100). This project aims to resituate NGO management goals within the moments of implementation where goals must be justified. I conclude here by discussing the impact of donors in shaping the educational agenda of local Ghanaian communities.

National governments use NGOs to create a social safety net to support low-income populations (Allard 2009: 31). NGOs have adaptability and flexibility that may be antithetical to more structured governments procedures (Michaux 2008:5). Policy makers can easily apply cultural judgments to their legislation and governance; public-private partnerships should seek to enhance the community in which such bureaucrats operate (Michaux 2008: 22). Some would say NGOs should not do the work of the government (Farmer 2003: 249), though NGOs have adaptability and imagination often lacking in the bureaucracy of political offices. To anthropologist James 
Ferguson, this alignment of the government's agenda with the NGO's agenda is problematic: "development uses the mask of poverty to increase state power" (Ferguson 1994: 256). In reality, educational NGOs are questioning the cultural assumptions implicit in national education models.

The Literacy Support program has made working with the formal system an important part of their program model. One manager says:

Our services target the out of school population the government is trying to reach. We advocate for improved methodology and are trying to get their methodology to be used in schools. The teaching method in formal schools needs to be changed to incorporate activity and discussion to keep students engaged. The government's plans to incorporate the [Literacy Support] model have progressed a lot. A draft of the policy has been written and on November 30 there will be a meeting to discuss further how this complementary system should be added (Personal Interview 11/15/2010).

Rather than bending to the conforming power that state education agendas may impose on subsistence farming communities, NGOs like Literacy Support are able to analyze and critique the effectiveness of national education from the community level. The Ghanaian Educational Service was working cooperatively with Literacy Support officials to brainstorm educational reform during my month in Tamale. Government officials, like donors, may rely on the NGOs' community lens to consider their intervention in development projects.

NGOs' funding supply is highly volatile and the constant quest for donors and financial support is inherent to any organization's management (Foster et al. 2009: 32). NGO staff must be able to meet the demand for social services using a limited supply of donors, who bring a personal, often morally charged, agenda along with their investment of labor or finances (Foster et al 2009: 34). Crewe and Harrison's ethnography, Whose Development? An Ethnography of Aid, highlights the contentious issue of NGO partnerships: "Given the good governance agenda, and aid conditionality, the portrayal of partnership as a process of cooperation between equals is inherently problematic" (Crewe and Harrison1998: 71). ${ }^{\text {iv }}$ But, through their institutional ethnography, the authors find recipients of NGO activity are not limited by the power imbalance present in the funding system (Crewe and Harrison 1998: 77). Organizations must market their cause to individuals, governments, and agencies that can provide financial support (Allard 2009: 31). Staff's ground level-lenses allows them to articulate locally relevant solutions to policy problems, but often they have to spend a disproportionate amount of their time searching for funding rather than implementing their ideas (Personal Interview 11/18/2010). Informants in Tamale regularly referred to funding when asked about current challenges facing their organization.

A manager of the Literacy Support program hints at a disconnect between the organization's and their primary donor's agendas when asked about current challenges to the future of their program. He noted:

The donor does not want to fund service delivery and
would prefer to do advocacy. We argue that if we do not
have classrooms where data can be collected, advocacy
cannot be done. Based on current patterns, by 2014
37,000 children will still be out of school. If donors hear
the news that Ghana now qualifies as a middle-income
country, they will be less compelled to donate.
(Personal Interview 11/15/2010).

The manager highlights a constant dilemma of NGO funding: do staff bend to the will of powerful donors, or stand behind their community's program ideas at the risk of losing funding?

Translating the reality of educational injustices in Tamale and Ghana to the world of corporate donors, philanthropists, and the public requires staff to invest time and energy away from their educational programs. "When a nonprofit finds a way to create value for a beneficiary ... it has not identified its economic engine. That is a separate step" (Foster et al. 2009:34). Foster et al. identify three parameters for defining ten of the main nonprofit funding models that are relevant here: "source of funds, the types of decision makers, and the motivations of the decision makers" (Foster et al. 2009: 35). The ten models they define apply to NGOs in the United States operational since 1970 or later which have grown to a budget at least fifty million dollars 
(Foster et al. 2009: 34). Literacy Support must either seek donors whose philanthropic motivations align with theirs, or the NGOs must shift their goals to align with available donors.

Two funding types roughly align with NGOs involved in this project. The first, "heartfelt connector," tries to communicate a social issue to the public that will resonate with a wide variety of people (Foster et al. 2009:35). Thus the primary motivation of funders is altruism (Foster et al. 2009: 37). The second, "local nationalizer," is an apt description for the Literacy Support program. Its issue, education, applies to more than one specific location, and the organization must gather funding from national and international sources, rather than just local ones (Foster et al. 2009: 37). A few individuals make funding decisions, and these funders are motivated by altruism (Foster et al. 2009: 37). Not only must NGOs carve out a particular niche in Tamale, they also must carve out a niche for funding.

Critical scholars argue ethnocentric discursive translation can be carried from fundraising to program implementation (Ferguson 1996, Goldman 2005, Kissane et al. 2004). In the institutional ethnography, Imperial Nature, Michael Goldman argues that Robert McNamera, long-time President of the World Bank, brought a neoliberal agenda to international development that is now the standard for any NGO development action (Goldman 2005: 98-99). McNamera advocated using education to further the training of poor communities (Goldman 2005: 71). Using the rational of cultural evolution, McNamera sought the economic goal of productive capitalism to improve impoverished countries globally (Goldman 2005: 71). McNamera was interested in remedying poverty with conformity: "his strategy was . . to measure, analyze, and overcome" (Goldman 2005:77). By highlighting training, productivity, and quantifiable outcomes, the World Bank fostered development rhetoric that says social justice is based on demographics rather than personal experiences. They funded NGO initiatives if their programs could be supported by quantitative data and measures of progress.

My fieldwork shows that prescriptive policy will be imperfectly planned or imperfectly implemented. Academic research cannot expect to form ideal plans for social action (Van Ufford et al. 2003: 18). As an ethnographer interested in empowerment, I must constantly evaluate the relationship of my work to the voices of oppressed people so "my thoughtful prescription for empowerment does not become an imposition of power itself" (Van Ufford et al. 2003: 18). Ethnographers cannot expect to inform the conversation on social injustice and NGOs without becoming an agent in processes of change, themselves (Mosse 2005: 18). Organizations must simultaneously reconcile the philanthropic vision of donors while building trust with student and families.

Further ethnographic work regarding NGOs and education is needed in oppressed communities (Bourgois 1996: 15). This project has illustrated that no matter our interest in management and policy, acute understanding of local cultural norms in poor communities is key to providing freedom from oppression (Michaux 2008: 22). NGOs in Tamale face similar challenges while working with oppressed communities. International organizations face a contradiction as they work to apply global policies to local context, while grassroots organizations are to respond dynamically to evolving and interrelated social processes. Policies and mission statements inform these actions, but do not confine or limit them (Mosse 2005:103).

\section{CONCLUSION}

Education can be a tool or a cage. It has been perceived as both an imposition of power and a source of empowerment (Freire 1970: 96). Teachers in NGO programs are able to invest as civically active members of the community when NGOs further the identity of their students and their community by prioritizing community networks over marketing the institution's image. It is difficult to simplify how any particular organization will apply its mission to individuals on any particular day. Being an educator in a Ghanaian community can mean saying “Good Morning!” to Ms. Rosa on her daily walk; communicating with parents; understanding family dynamics; and making academics relevant to each student. The work of NGO teachers becomes community outreach work: it requires reconciling multiple moral and ethical standards on a daily basis.

Today, there is no certain proof that the sustainable engagement of NGOs will strengthen the civic fabric and reduce the poverty of Tamale. Ultimately, I hope a continual process of engagement can inform educational curriculums in oppressed places. No NGO agenda is imposed without being altered by the social situation where it is implemented (Mosse 2004: 641). Assuming no dialogue can take place without improper imposition 
will maintain oppression of Tamale residents. Policies are not impenetrable structural forces; their effects are complemented by local cultural reality. Yon concludes, after completing ethnographic work at Canadian schools, "power emerges through these [educational] practices not as zero-sum and hierarchically held but dispersed; not as unidirectional, as might be envisaged, but as multidirectional" (1999: 38). If academic theory increasingly gives value to the role of institutional employees as translators of policy, we will gain a view of community development that negotiates power and admits its own limitations.

A high school counselor in Tamale describes his job as facilitating vocational training and career counseling for students. However, he notes, rather than prescribing paths for students, counselors should attempt to "guide their interests and open up opportunities where they think they are not possible... the choice is in their hands" (Personal Interview 11/12/2010). While managers in Tamale are motivated by overemphasizing economic benchmarks, local teachers are situated to re-localize education to foster the functionality of marginalized communities on their own terms. Rather than neglect the quantifiable agendas of governments and funding agencies, sustainable relationships must be balanced with a sustainable management model to provide stability for service delivery. Through this contested process of development NGOs' educational agendas must hand communities back to students and allow them to develop their own identity with pride while gaining skills that allow accessibility to social contexts beyond their own. i Today there are many terms, applications, and definitions associated with the term 'development,' and though many NGOs use the word while keeping in mind what local communities value as a 'development,' when using the biological analogy of Darwinian evolution, social development become analogous to Durkheim's social theory regarding the progression of societies from 'traditional' to 'modern.' (Lewis 2005; Escobar 1992: 140)

ii "Even the most cursory look at data suggests that as aid has increased over time, Africa's growth has decreased with an accompanying higher incidence of poverty (Moyo 2009: 46).

iii Bringing formal education to Ghana has been a source of conflict often seen by the political elite as a way to exert power over diverse and fragmented ethnic groups across the country. This is not only the case in the North, but across the country. Roberts' study of education in Wiawso, Western Ghana found missionaries imposed a Western curriculum on the community around 1900, despite the community's hesitation and reluctance (1982: 269)

iv Crewe and Harrison (1998: 71) are referring to the World Bank's interest in partnering with local NGOs to 'fight poverty' globally based on their generalized global agenda.

In October 2010, news was released that Ghana's socioeconomic demographics now enable it to qualify as a middle-income country. Some praised the achievement of the country to reach this benchmark, while other questioned the global standards (ghanaweb.com).

vi The social theorist, Durkheim, proposed that societies naturally evolve from 'traditional' to 'modern' societies. Dominant anthropology theory has moved away from this modernization theory since the 1970's (Lewis 2005). 


\section{BIBLIOGRAPHY}

Apple, Michael W. 1982. Education and Power. Boston: Routledge \& Kegan Paul.

Botchway, Karl. 2001. Are Development Planners Afraid of History and Contextualization? Notes on Reading a Development Report on Northern Ghana.Canadian Journal of African Studies. 35 (1): 32-66

Bourgois, Philippe I.1995.In Search of Respect: Selling Crack in El Barrio. Cambridge: Cambridge University Press.

Bourdieu, Pierre.1973. Cultural Reproduction and Social Reproduction. In Knowledge, Education, and Cultural Change ed. Richard Brown Tavistock: London.

Burbules, Nicholas C., and Carlos Alberto Torres.1999. Globalization and Education: Critical Perspectives. New York, NY: Routledge.

Casely-Hayford, Leslie, and Adom B. Ghartey. 2007. The Leap to Literacy and Life Change in Northern Ghana. SfL Internal Impact

Cheater, Angela P. 1999. Power in the Postmodern Era. In The Anthropology of Power: Empowerment and Disempowerment in Changing Structures ed. Cheater, Angela Pp. 1-12. London: Routledge.

Clark, John. 1992. Democratising Development: NGOs and the State. Development in Practice 2(3): 151-62

Crewe, Emma, and Elizabeth Harrison. 1998. Whose Development?: An Ethnography of Aid. London: Zed Books.

Escobar, Arturo.1992. Planning. In The Development Dictionary: A Guide to Knowledge as Power. Wolfgang Sachs, ed. Pp.132-145. London: Zed Books.

Farmer, Paul. 2003. Pathologies of Power: Health, Human Rights, and the New War on the Poor. Berkeley: University of California Press.

Ferguson, James. 2005. Anthropology and Its Evil Twin: Development the Constitution of a Discipline. In The Anthropology of Development and Globalization: From Classical Political Economy to Contemporary Neoliberalism. Malden, MA: Blackwell Pub.

Ferguson, James. 1994. The Anti-politics Machine: “Development," Depoliticization, and Bureaucratic Power in Lesotho. Minneapolis: University of Minnesota Press.

Foster, W. L., P. Kim, and B. Christiansen. 2009.Ten Non-Profit Funding Models. Standford Social Innovation Review 32-39

Foucault, Michael. 1979. The History of Sexuality. London: Allen Lane

Freire, Paulo. 2000. Pedagogy of the Oppressed. New York: Continuum.

Ghana Web.2010 6 November. Business News: Ghana Attains Middle Income Status. < http://www.ghanaweb.com/ GhanaHomePage/NewsArchive/artikel.php?ID=196857> Accessed 5 April 2012

Goldman, Michael. 2005. Imperial Nature: The World Bank and Struggles for Social Justice in the Age of Globalization. New Haven, CT: Yale University Press.

Gronbjerg, K. A., and L. Paarlberg. 2001. Community Variations in the Size and Scope of the Nonprofit Sector: Theory and Preliminary Findings. Nonprofit and Voluntary Sector Quarterly 30 (4): 684-706.

This work is licensed

under a Creative

Commons Attribution-

NonCommercial

NoDerivs 3.0

Unported License.

Gronemeyer, Marianne. 1992. Helping. In The Development Dictionary: A Guide to Knowledge as Power. Wolfgang Sachs, ed. Pp.53-70. London: Zed Books.

Guo, C; Acar, Muhittin. 2005. Understanding Collaboration Among Nonprofit Organizations: Combining Resource Dependency, Institutional, and Network Perspectives. Nonprofit and Voluntary Sector Quarterly 34(3): 340-61.

Harsh, Matthew, Paul Mbatia, and Wesley Shrum. 2010. Accountability and Inaction: NGOs and Resource Lodging in Development. Development and Change 41(2): 253-78. 
Kissane, Rebecca J. 2004. Do You See What I See? Nonprofit and Resident Perceptions of Urban Neighborhood Problems. Nonprofit and Voluntary Sector Quarterly 33(2): 311-33.

Lewis, David. "Anthropology and Development: The Uneasy Relationship." Accessed March 15, 2012.

Markham, W. T., M. A. Johnson, and C. M. Bonjean.1999. Nonprofit Decision Making and Resource Allocation: The Importance of Membership Preferences, Community Needs, and Interorganizational Ties. Nonprofit and Voluntary Sector Quarterly 28 (2): 152-84.

Melkote, Srinivas R., and H. Leslie. Steeves. 2001. Communication for Development in the Third World: Theory and Practice for Empowerment. New Delhi: Sage Publications.

Michaux, Melissa B. 2008. When Welfare Worked: A Community Approach to Welfare Reform. Polity 40(1): 1-23.

Mosse, David.2004. Is Good Policy Unimplimentable? Reflections on the Ethnography of Aid Policy and Practice. Development and Change 35(4):639-71

Mosse, David. 2005 Cultivating Development: An Ethnography of Aid Policy and Practice. London: Pluto Press.

Moyo, Dambisa. 2009. Dead Aid: Why Aid is Not Working and How There is a Better Way for Africa. New York: Farrar, Straus and Giroux.

Nussbaum, Martha Craven. Creating Capabilities: The Human Development Approach. 2011. Cambridge, MA: Belknap Press of Harvard University Press,

Ospina, S., W. Diaz, and J. F. O'Sullivan. 2002. Negotiating Accountability: Managerial Lessons from Identity-Based Nonprofit Organizations. Nonprofit and Voluntary Sector Quarterly 31 (1): 5-31.

Ogbu, John U.1981. School Ethnography: A Multilevel Approach. Anthropology and Education Quarterly 12(1): 3-29.

Penner, L. A. 2000.Promoting Prosocial Actions: The Importance of Culture and Values. The Journal of Social Philosophy 477-87.

Quarles, Van Ufford, Ph., and Ananta Kumar. Giri. 2003.A Moral Critique of Development: In Search of Global Responsibilities. Mirano, Venice: EIDOS.

Rahnema, Majid.1992. Poverty. In The Development Dictionary: A Guide to Knowledge as Power. Wolfgang Sachs, ed. Pp.158-176. London: Zed Books.

Rajak, Dinah. 2006. Cultivating Development: An Ethnography of Aid Policy and Practice by David Mosse. Oxfam GB 16 (3/4): 378-80.

Roberts, P. A.1982. Whose School? Conflicts over School Managment in Sefwi Wiawso, Ghana. Anthropology and Education Quarterly 13 (3): 268-78.

Scheper-Hughes, Nancy. 1992. Death without Weeping: The Violence of Everyday Life in Brazil. Berkeley, CA: University of California Press.

Sen, Amartya. 1999. Development as Freedom. New York: Knopf.

Shaikh, Alanna. "Three Cups of BS." Foreign Policy - the Global Magazine of Economics, Politics, and Ideas. April 19, 2011. Accessed August 29, 2011. http://www.foreignpolicy.com/articles/2011/04/19/three_cups_of BS.

Wade, Nicholas. 2010. Anthropology a Science? Statement Deepens a Rift. New York Times. December 9.

World Bank.2011. Feed the Future: Ghana. Feedthefuture.gov/country/Ghana. Accessed 15 April 2012.

Wong, Nga-Wing Anjela. 2008."They See Us as a Resource:" The Role of a Community-Based Youth Center in Supporting the Academic Lives of Low-Income Chinese American Youth. Anthropology \& Education Quarterly, 39(2):181-204.

Yon, Daniel. "The Discursive Space of Schooling." In The Anthropology of Power: Empowerment and Disempowerment in Changing Structures, by Angela P. Cheater, 28-41. London: Routledge, 1999. 